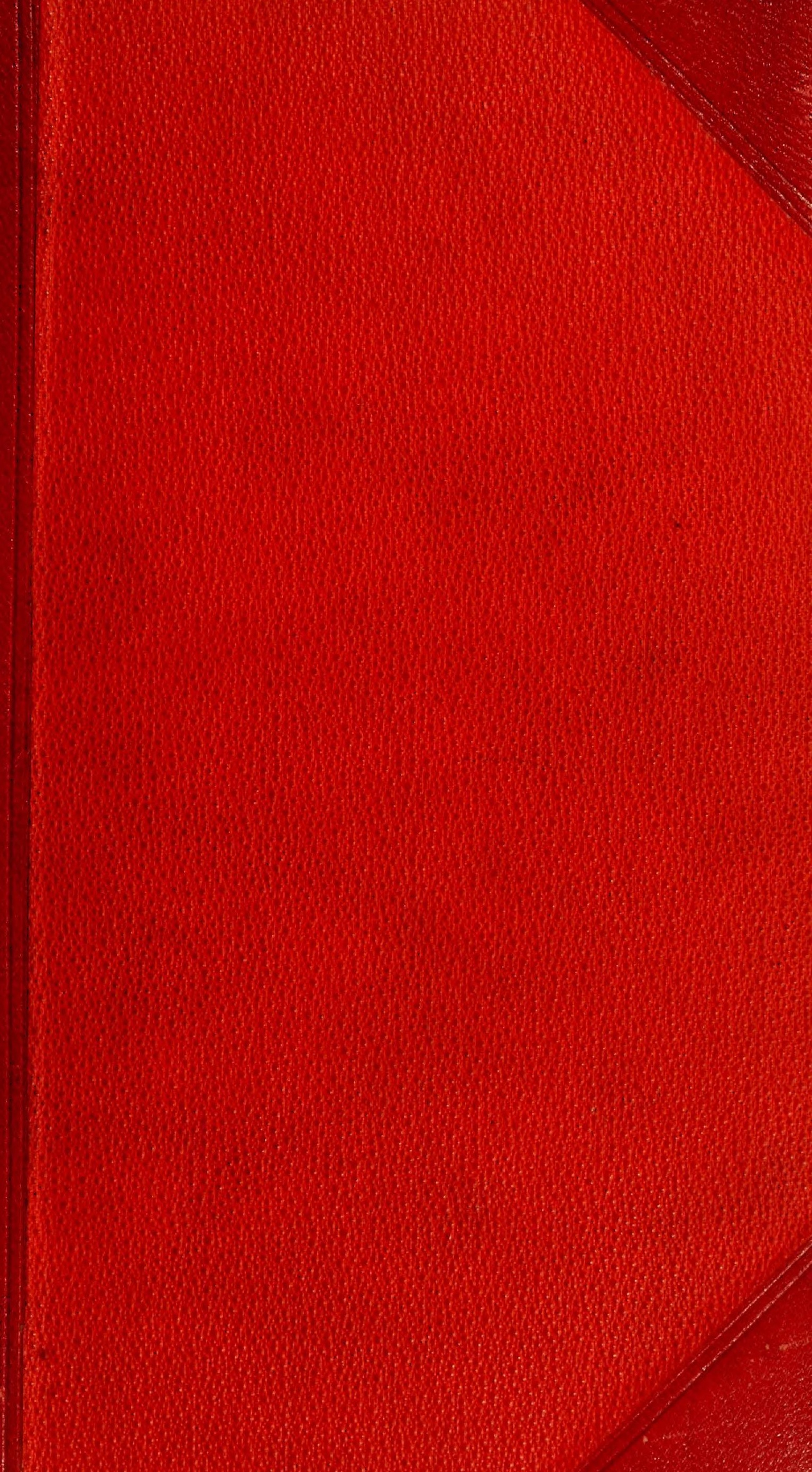


\$ Mollnsps
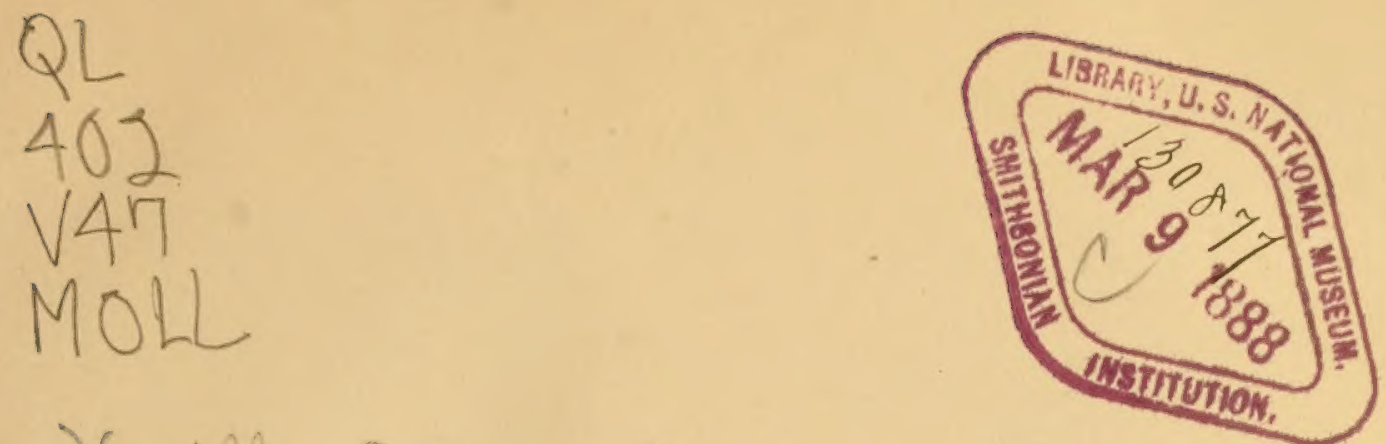

Verrill, Addison 8

Collected wasks.

mollusks.

(Binders titte)

Division of Mollusites Sectional Library

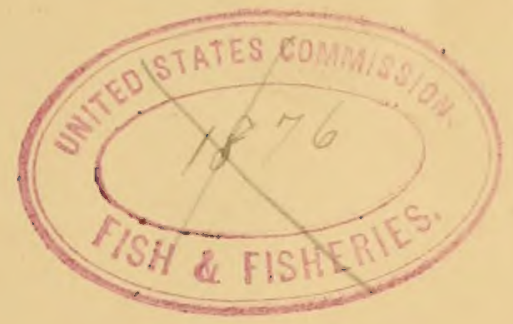



N. E. Astarte crenata Gray $(=A$. Tens Stimp.).

* s. Leda unea Gould.

* N. E. Leda pernula (Miill.).

* E. Toldia expansa Jeff. ?

*. E. Yoldia frigida Torell.

*. G. E. Arca glacialis Gray.

N. E. Area pectunculoides Scacchi.

* E. Limopsis cristata Jeff.?
* E. Limopsis minuta (Phil.).

* Modiola polita V. \& S.

* S. Avicula hirundo? var. nitida V.

* .. E. Pecten vitreus (Gmel.) Wood.

N. E. Pecten Hoskynsi Forbes, var. pustulosus $\mathrm{V}$.

* E. Pecten fenestratus Forbes?

* Pecten, sp. (near opercularis).

* E. Limaea subovata (Jeff.) Monter.

\section{PART III.-CATALOGUE OF MOLLUSCA RECENTLY ADDED TO THE FAUNA OF SOUTHERN NEW ENGLAND.}

\section{By A. E. VERRILL.}

The following lists include 130 species of Mollusca that have recently been added to the fauna of Southern New England, mainly through the researches of the dredging party of the United States Fish Commission on the steamer "Fish Hawk". The greater portion of these, with several others undetermined or not yet described, were taken on September 4 and 13 and October 2, on the outer bank or slope, 70 to 115 miles south from Martha's Vineyard and Newport, R. I., in 65 to 500 fathoms. For a list of these localities see p. - -

In these lists those species which were unrecorded from or entirely new to New England or to the northeastern coast of America are indicated by an asterisk; previously undescribed species by two asterisks; those known previously from our northern coasts have $\mathrm{N}$ prefixed; those from the middle parts of the coast have $\mathrm{M}$, and are neither specially southern nor northern ; those oceanic species belonging to the surface fauna have o prefixed; southern forms are designated by s; those that are also known from Europe are designated by E; those peculiar to America by $A$.

In the tables, living specimens are indicated by an asterisk; dead ones by a dagger ; $m$ signifies many; $s v$, several ; $r$, rare; $l$, unusually large; $j$, young.

List of Mollusca from the outer banks previousty unknown south of Cape Cod.

\begin{tabular}{|c|c|c|c|c|c|c|c|c|}
\hline & Stations .... & $\begin{array}{c}865 \\
\text { to } \\
867\end{array}$ & $\begin{array}{l}872 \\
\text { to } \\
874\end{array}$ & $\begin{array}{l}870 \\
\text { to } \\
878\end{array}$ & 869 & $\begin{array}{l}879 \\
880 \\
895\end{array}$ & $\begin{array}{l}893 \\
894\end{array}$ & $\begin{array}{l}891 \\
892\end{array}$ \\
\hline & Depths in fathoms........ & $\begin{array}{l}64 \\
\text { to } \\
65\end{array}$ & $\begin{array}{c}85 \\
\text { to } \\
100\end{array}$ & $\begin{array}{l}115 \\
\text { to } \\
155\end{array}$ & 192 & $\begin{array}{l}225 \\
\text { to } \\
252\end{array}$ & $\begin{array}{l}365 \\
\text { to } \\
372\end{array}$ & $\begin{array}{l}487 \\
\text { to } \\
500\end{array}$ \\
\hline *** & $\begin{array}{l}\text { CEPHALOPODA. } \\
\text { Callitenthis reversa Verrill }\end{array}$ & & & & & & & \\
\hline 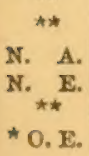 & 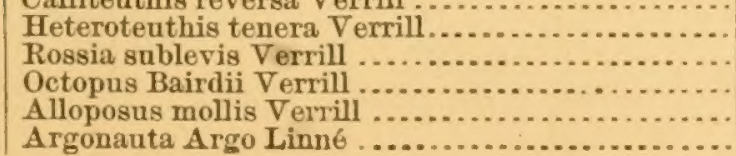 & *im. & ${ }^{*} \mathrm{~m}$. & $\begin{array}{l}\ldots \\
{ }^{*} \mathbf{m} \\
* 2 \\
* \text { sv. } \\
\cdots \\
\cdots\end{array}$ & 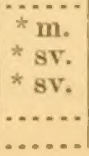 & 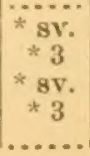 & $\begin{array}{c}* 1 \\
* 2 \\
* 8 v \\
\star 2 \\
2\end{array}$ & $\begin{array}{l}\cdots \\
\cdots \\
* 1 \\
+3\end{array}$ \\
\hline
\end{tabular}


List of Mollusca previously unknown south of Cope Cod-Continued.

\begin{tabular}{|c|c|c|c|c|c|c|c|c|}
\hline & Stations. & $\begin{array}{c}865 \\
\text { to } \\
867\end{array}$ & $\begin{array}{c}872 \\
\text { to } \\
874\end{array}$ & $\begin{array}{c}870 \\
\text { to } \\
878\end{array}$ & 869 & $\begin{array}{l}879 \\
880 \\
895\end{array}$ & $\begin{array}{l}893 \\
894\end{array}$ & $\begin{array}{l}891 \\
892\end{array}$ \\
\hline & Depths in fathoms. & $\begin{array}{l}64 \\
\text { to } \\
65\end{array}$ & $\begin{array}{c}85 \\
\text { to } \\
100\end{array}$ & $\begin{array}{c}115 \\
\text { to } \\
155\end{array}$ & 192 & $\begin{array}{c}225 \\
\text { to } \\
252\end{array}$ & $\begin{array}{c}365 \\
\text { to } \\
372\end{array}$ & $\begin{array}{c}487 \\
\text { to } \\
500\end{array}$ \\
\hline & GASTROPODA. & & & & & & & \\
\hline N. E. & 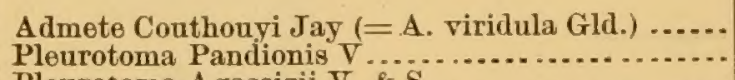 & & & ${ }^{*}$ sv. & ${ }^{*} \mathbf{m}$. & ${ }^{*} \mathbf{s}$ & * $\mathbf{s v .}$ & ${ }^{*} \mathbf{m}$ \\
\hline$* *$ & 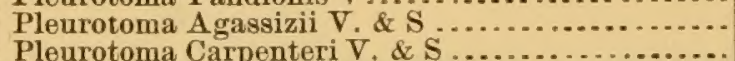 & & +1 & $\begin{array}{c}4 \\
* \\
* \\
*\end{array}$ & +1 & * sv. & & ${ }^{*} \mathbf{m}$. \\
\hline * N. E. & 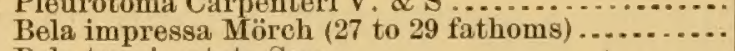 & & & & …... & $\cdots \cdots$ & & \\
\hline$\approx$ N. E. & 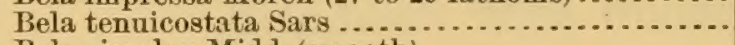 & & & ........ & ...... & & * 3 & \\
\hline$* \underset{* *}{N} \mathbf{E}$ & $\begin{array}{l}\text { Bela simplex Midd. (smooth) } \ldots \ldots \ldots \ldots \\
\text { Bela hebes Verrill }\end{array}$ & & & & & & $\dagger 1$ & $\ldots \ldots$ \\
\hline N. E. & Bela violacea (Migh.) Ad. (27 to 29 fathoms) .... & & & & & & & \\
\hline N. $\mathbf{E}$ E. & 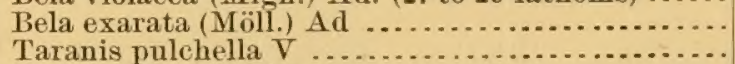 & & & & $\cdots$ & $* 1$ & 2 & $\begin{array}{ll}* 1 \\
*\end{array}$ \\
\hline 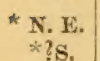 & 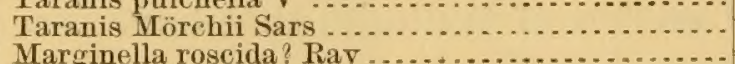 & & & $\cdots$ & $\ldots .$. & $\cdots$ & +2 & ( \\
\hline N. A. & 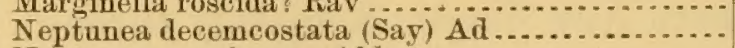 & $\begin{array}{l}T \\
+1\end{array}$ & & t sv. & & & & \\
\hline${ }_{*}^{*}$ N. E. & 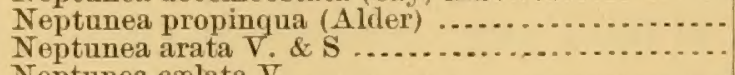 & $\begin{array}{c}\dagger \\
\cdots\end{array}$ & $\begin{array}{l}\text { tsv. } \\
\text { tsv. }\end{array}$ & $\begin{array}{l}* \mathrm{~m} . \\
\text { * } \mathrm{s} \text {. }\end{array}$ & m. & $\mathbf{m}$ & ${ }_{*}^{*} \mathrm{~m}$ & \\
\hline ** & 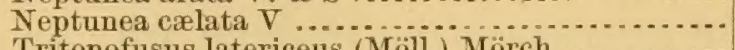 & & & & ...... & * sv. & $* \mathbf{m}$. & m. \\
\hline${ }^{*}$ N. E. & 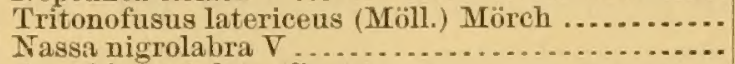 & & & $* 1$ & $\cdots \ldots$ & $\begin{array}{l}* \text { sv. } \\
\ldots . . . .\end{array}$ & $\begin{array}{l}+8 v . \\
\ldots \ldots .\end{array}$ & $\begin{array}{ll}\cdots \\
\cdots \cdots\end{array}$ \\
\hline N. E. & 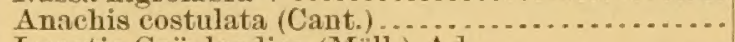 & & & & $* \mathrm{~m}$. & * sv. & & \\
\hline N. E. & Lunatia Grönlandica (Möll.) Ad .................. & ....... & +1 & $1 \mathrm{sv}$ & $\dagger \mathrm{sv}$ & t sv. & & \\
\hline N. E. & & & & $\cdots \cdots$ & 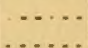 & $\cdots+$. & & $\cdots$ \\
\hline${ }_{* * *}^{*} \mathrm{~N}$. & 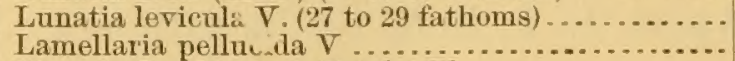 & & * sv. & * sv. & $\cdots$ & $\mid \cdots \ldots$. & & \\
\hline * N. I. & Cingula Jan-Mayeni (Friele) $\nabla . . . . . . . . . . . . . .$. & & & & & $* 1$ & ${ }^{*} \mathrm{~m}$. & m. \\
\hline N. A. & 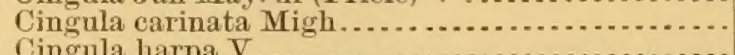 & & 2 & $* 2$ & & ...... & & \\
\hline *** N. & 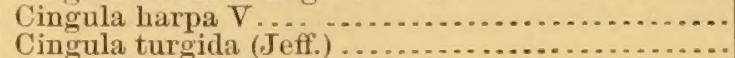 & & $\cdots$ & $\cdots$ & .... & $\cdots$ & +2 & \\
\hline *N. E. & 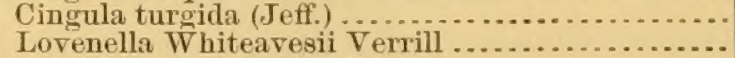 & & & .... & & ... & & +1 \\
\hline $\begin{array}{ll}* * & \text { N. } \\
\text { N. A. } & \text { A. }\end{array}$ & 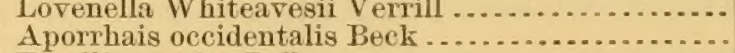 & & $\dagger$ & $\mathrm{m}$. & +23 & +2 & 2 & * sv. \\
\hline N. E. & Torellia ves ita Jeff.... ..... & & +1 & * $\mathrm{sv}$. & $\frac{12}{12}$ & & 2 & \\
\hline$* *$ & Lepetella tubicola $\nabla$. \& S.. & & ...... & +1 & $* \mathbf{m}$. & $* 3$ & ${ }^{*} \mathrm{~m}$. & \\
\hline *N. E. & Acmæa rubella (Fabr.) ............................... & & & $\because$ & & & +1 & \\
\hline ** & 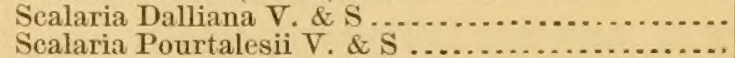 & & $\begin{array}{l}\dagger \\
* t\end{array}$ & * sv. & ${ }^{*} 3$ & ... & & \\
\hline$* *$ & 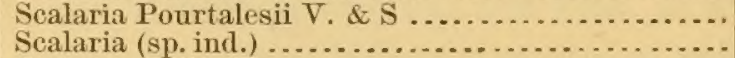 & & $\begin{array}{l}* \dagger \\
* 1\end{array}$ & † sv. & & $\cdots$ & & \\
\hline$\stackrel{*}{*}$ & 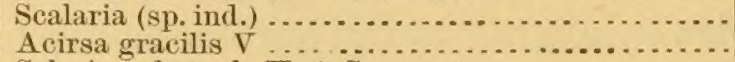 & & & … & & $\cdots$ & +9 & $* 1$ \\
\hline$* *$ & Solarium boreale $\vec{V} . \& \mathrm{~S} . . . . . . . . . . . . .$. & & & $\because \bar{r}$ & & & & *1 \\
\hline ** N. & 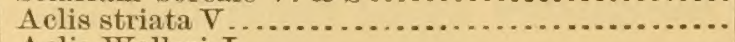 & & & $\dagger 1$ & & & & \\
\hline *N.E. & 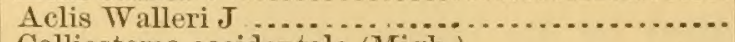 & & & ...... & & & * 3 & $\times 1$ \\
\hline N. E. & 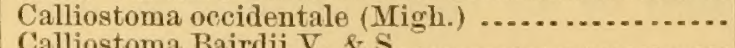 & & & $\ldots . .$. & & ... & $* 1$ & \\
\hline $\begin{array}{l}* * \\
* *\end{array}$ & $\begin{array}{l}\text { Calliostoma Bairdii } \mathrm{V} \text {. \& } \mathrm{S} \ldots \ldots \ldots \ldots \ldots \ldots \ldots \ldots \ldots \\
\text { Margarita regalis } V \text { \& } \mathrm{S} \ldots \ldots \ldots \ldots \ldots \ldots\end{array}$ & $\dagger$ & $* \mathrm{~m}$. & * $\mathrm{m}$ & ${ }^{*} \mathbf{m}$. & 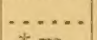 & & \\
\hline$* *$ & Margarita lamellosa $v . \& \mathrm{~s} . . . . . . . . . . . .$. & & $\begin{array}{c}\text { †sv. } \\
+1\end{array}$ & $\because+1$ & & ${ }^{*} \mathbf{m}$. & 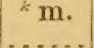 & \\
\hline * E. & 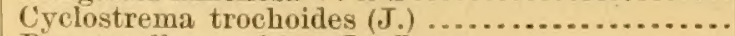 & & & & & & $* 2$ & +2 \\
\hline N. E. & Puneturella noachina (L.) Lowe .............. & & & & & $\approx 1$ & & \\
\hline E. & Eulima intermedia Cantr .. & & .... & * sv. & ...... & ...... & & \\
\hline * E. & Eulima distora Desh ...... & & ...... & $* 1$ & .... & ....... & ..... & \\
\hline N. A. & Turbonilla nivea (St.) Ad ........... & & & $* 1$ & $\ldots \ldots$ & ...... & $\cdots$ & \\
\hline $\begin{array}{l}* * \\
* *\end{array}$ & 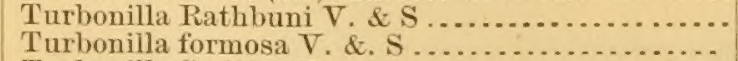 & & & $\cdots$ & sv. & * sV. & & $\because$ sv. \\
\hline ** & ii $V$ V & & $* 1$ & $* \mathrm{sv}$. & & & & \\
\hline ** & Odostomia sulcat & & .... & +1 & & & & \\
\hline N. E. & Odostomia unidentata (1) & & & $\dagger 1$ & & & ... & \\
\hline *N. E. E. & $\begin{array}{l}\text { Auriculina insculpta? } \\
\text { Eulimella ventricosa Fo }\end{array}$ & & $* i$ & $\cdots$ & & & & $\ldots$ \\
\hline N. A. & $\begin{array}{l}\text { Eummella ventricosa } F \\
\text { Ringicula nitida } V \text {.... }\end{array}$ & & ..... & * sv. & & SV. & sv. & $¥ 2$ \\
\hline N. E。 & neto-striata (Migh.) Ad ....... & & & * m. & sv. & $* \mathbf{m}$. & $* \mathbf{m}$ & * sv. \\
\hline * N. L. & Philine Finmarchica Sars..... & & & & & & $\because 3$ & \\
\hline${ }^{*}$ N. E. & $\begin{array}{l}\text { Philine cingulata Sars ......... } \\
\text { Philine amabilis } V\end{array}$ & & & $* 3$ & & & $* 1$ & $* 1$ \\
\hline * $\quad$ E. & Amphisphyra globosa Lovén. & & & +4 & & & +3 & \\
\hline N. E. & Amphisphyra pellueida (Brown) Lovén......... & & & +2 & & .... & $*_{1}$ & \\
\hline$* \quad E_{0}^{*}$ & Diaphana gemma $V$ & & & $* 1$ & & $\cdot$ & $\cdots$ & \\
\hline${ }^{*}$ N. E. & $\begin{array}{l}\text { Draphana conulus (Desh.) } \\
\text { Diaphana nitidula (Lor.) ....... }\end{array}$ & & & & & & +4 & sv. \\
\hline N. E. & 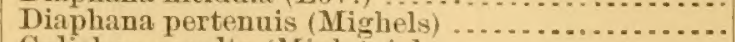 & & & * & & & +1 & \\
\hline N. E. & 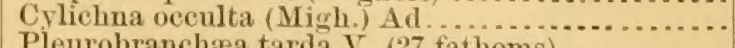 & & 1 & $\dagger 1$ & & & * sv. & * sv. \\
\hline$* *$ & 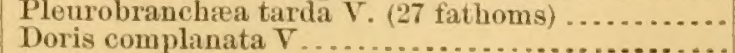 & ${ }^{*} \mathrm{~m}$. & * $\mathrm{m}$. & ${ }^{*} \mathrm{~m}$. & & & & \\
\hline * $\quad 0$. & Carinaria Atlantica $\mathrm{Ad} . \& \mathrm{R}$. & to. & & & & & & \\
\hline
\end{tabular}


PROCEEDINGS OF UNITED STATES NATIONAL MUSEUM. 407

List of Mollusca previously unknown south of Cape Cod-Continued.




List of Mollusca from the outer banks previously known from the shallow waters south of Cape Cod.

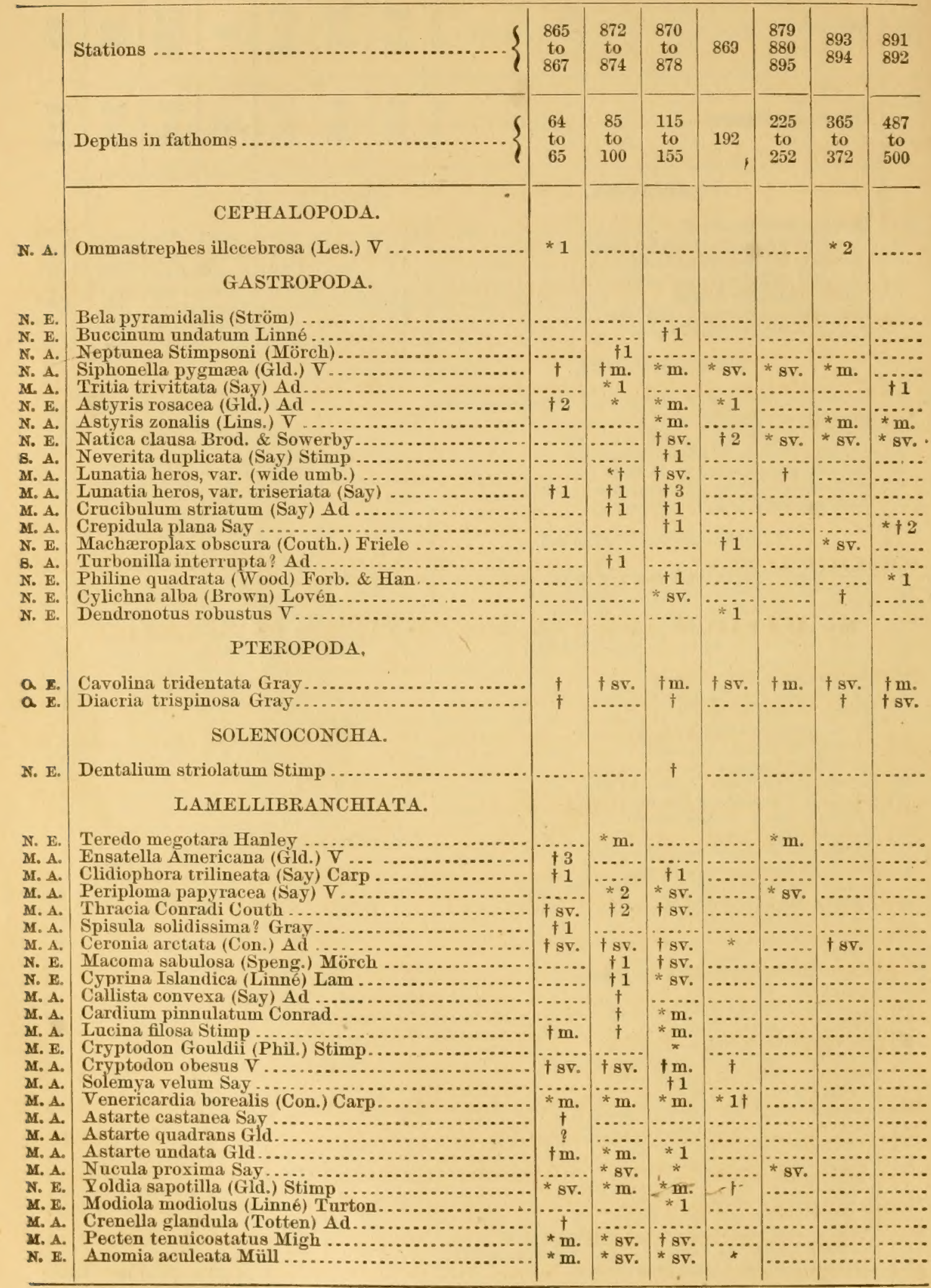


List of recent additions to shallow-water Mollusca of Southern New England.*

Parasira catenulata Steenstrup. Oceanic. Mediterranean.

*Truncatula truncatulus (Drap.). Littoral. European.

Littorina littorea. Littoral; abundant. European.

* Assiminea Grayana Leach. Littoral. European.

Ancula cristata Lovén. Northern and European.

**Polycerella Emertoni Verrill. Littoral.

Scyllaca Edwardsii Verrill. Littoral. Southern and oceanic.

Coryphella Mananensis (Stimp.) Verrill. Off Race Point, Long Island Sound, 40 fathoms.

Stiliger fuscata, (Gld.) Bergh. Massachusetts Bay.

Terebratulina septentrionalis (Couth.). Off Block Island, 15 fathoms. Northern.

DESCHIPTION OF A NEW SPECIES OF NEMHCHTHYS (NEMICHTHYS AVOCETTA), FIROM PUGET SOUND.

By DAVID S. JORDAN and CHARLES H. GILBERT.

Nemichthys avocetta, sp. nov.

Color translucent white, the lower half of the body covered with small, round, black spots, sharply defined; among these some smaller spots. Belly near the median line black. Upper half of body plain, colorless. Pectorals and dorsal plain. Anal speckled.

Body band-shaped, but not strongly compressed; deepest in the middle, tapering behind to the long and very slender filament-like tail, and anteriorly to a very long and slender neck, which contracts immediately behind the head. Skin smooth. No lateral line.

Head proper small, short and rather broad; concave between the eyes, with two median ridges; full and broad behind the eyes, with three longitudinal ridges. Lower part of head narrow, sharp, so that the head would be triangular in a vertical section. Eye very large, vertically placed, its length one-third that of the head without snout. Nostrils each simple (two on each side), rather large, close in front of eye, without tube or flap. Maxillary extending to close behind the eye, the mandible somewhat farther. Jaws prolonged, becoming very slender, long, acuminate, needle-like at tip, somewhat recurved. Upper jaw the longer, and nearly four times the length of the rest of the head, being 7-8 times its greatest depth. Both jaws with small, very numer-

* Some of the species here included were discovered in 1875 and 1876, and have been recorded in the American Journal of Science. Those with an asterisk prefixed were first discovered on our coast this season, or else have not been previously recorded. For additional species, not included in my Report on Invertebrates of Vineyard Sound, \&c., 1873, see American Journal of Science, x, pp. 40, 41, July, 1876. 
ous, retrorse, close-set, sharp teeth. Jaws bony, their lateral surfaces with retrorse roughnesses. Head naked, covered with skin.

Gill-openings rather large, oblique, running downward and forward, separated by a rather narrow isthmus. Pectorals well developed, half longer than eye. No ventrals. Vent under middle of the length of the pectorals (when depressed); the anal fin beginning close behind it and extending to the tail; its rays soft and rather slender; the membrane delicate; its height greatest near the middle and anteriorly, where it is somewhat less than height of body, becoming obsolete on the long caudal filament. Dorsal similar to anal, but lower, beginning close behind the occiput and running to the tail.

Table of measurements.

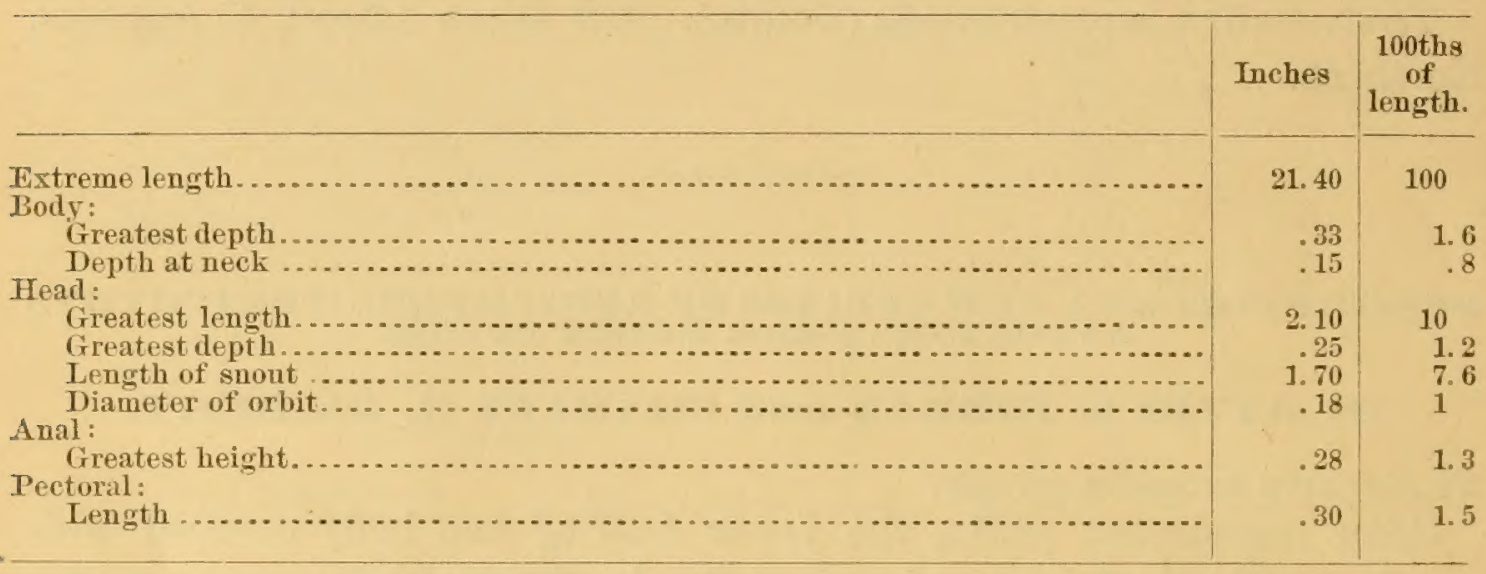

The specimen which is the type of the present description was taken in May, 1880, in the harbor of Port Gamble, and was placed by its captor in the museum of the University of Washington Territory, at Seattle. The president of the university, Prof. A. J. Anderson, presented it to the United States National Museum. Its movements in the water are said to be extremely active.

Fishes of this type offer comparatively few specific characters, and we are able to separate this species from Nemichthys scolopaceus Rich. of the Atlantic by differences in proportion only. According to the detailed description and figure of the latter species given by Lowe and Brandt (Leptorhynchus or Belonopsis leuchtenbergi, Mém. Acad. St. Pétersb. Sav. Etrang., 1854, vii, 171-174), Nemichthys avocetta is distinguished by the much slenderer head, longer beak, and higher anal fin, the greatest height of the latter being nearly equal to the length of the pectoral and more than the depth of the head. So far as known to us, this is the first species of the genus thus far taken in the Pacific. A recent newspaper account of the capture of a sea-serpent at Victoria, British Columbia, perhaps refers to a second example of the same species.

Seattle, Wash., June 10, 1880. 



152

(2)

22

35

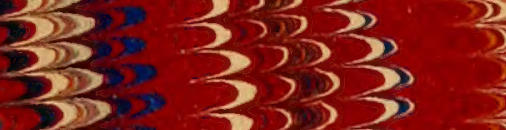

$32,335,35$

$52: \frac{3}{3} 30,3$

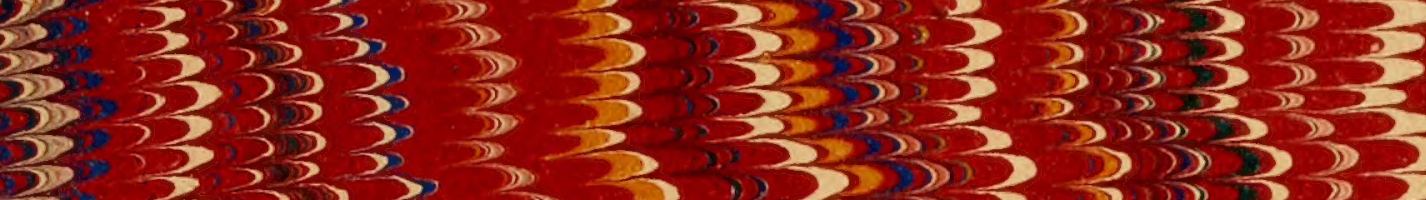

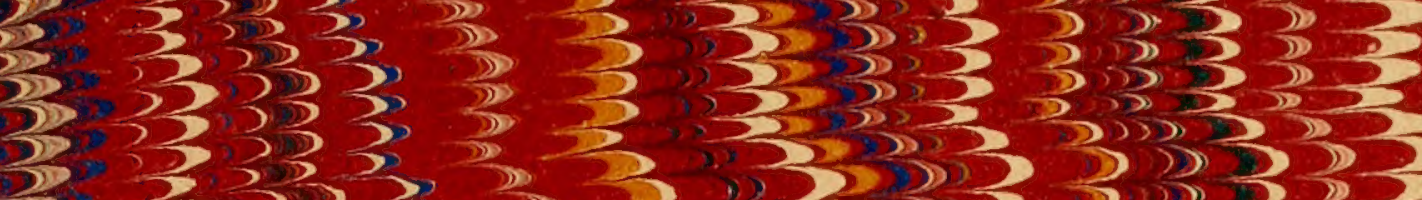

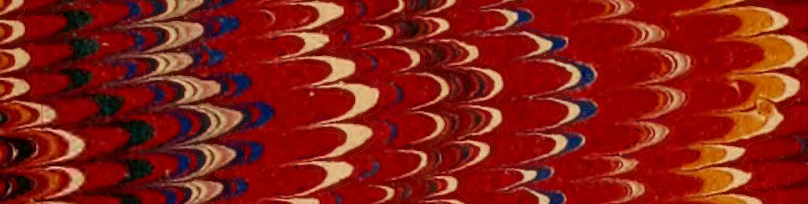

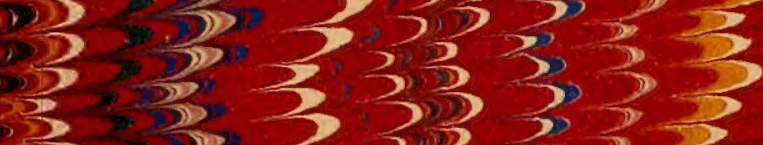

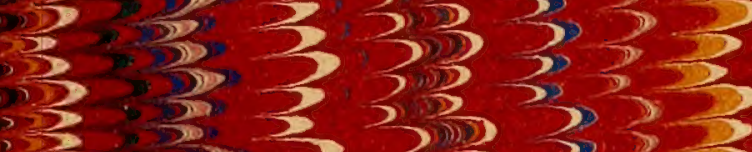

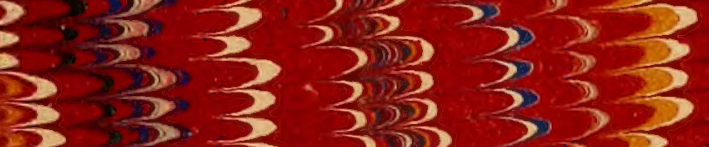

$33,323,323$

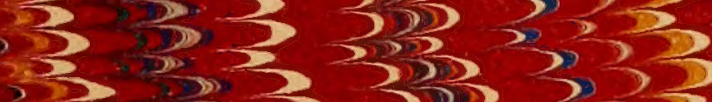

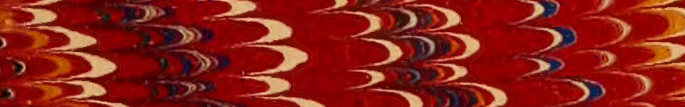

$32,5,3,2532$

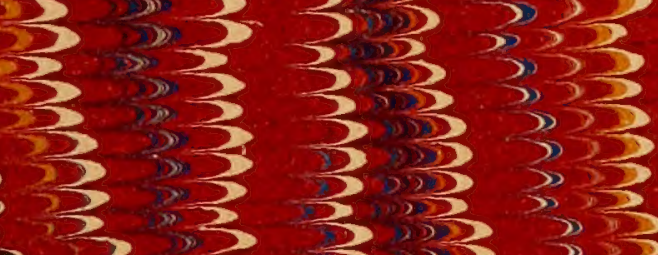

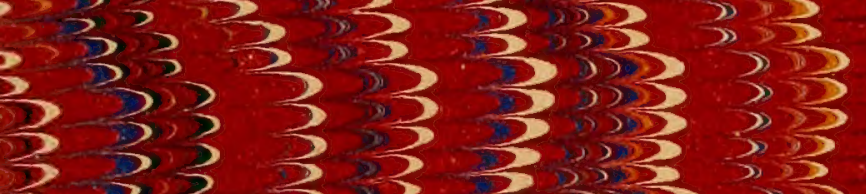

3

$3,3,3, \frac{3}{3}, 3,3$ $\sum_{3} \sum_{2}^{\infty}$ $3_{3}^{3} 33_{3} 3 \underbrace{}_{3}$

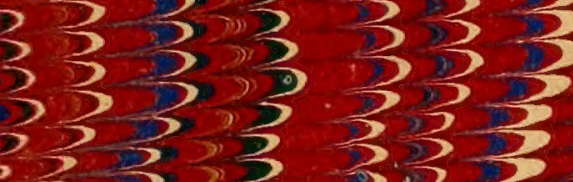

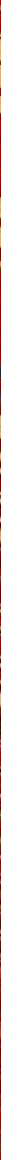

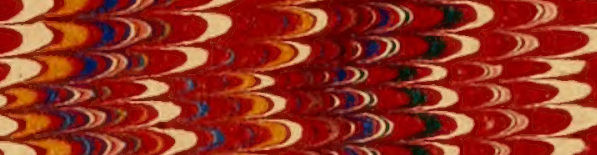

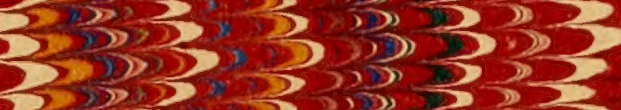

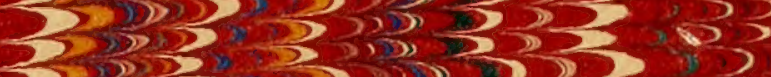
2503250202

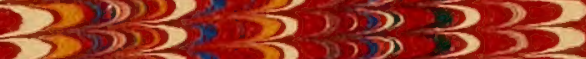

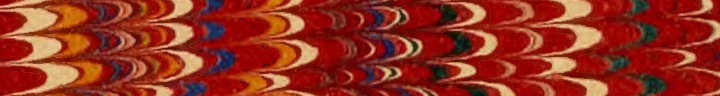

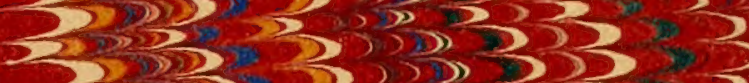
$35203,35,53$

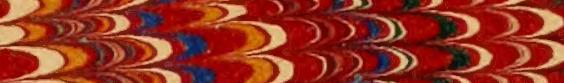
300025,535 3502353

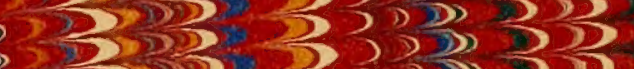
23502532 $32500,3,5,3,3$

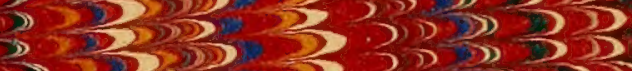

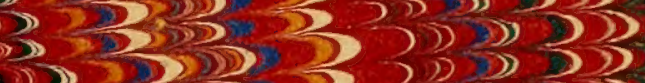

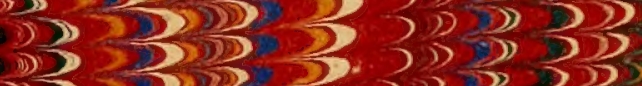
D) 350253

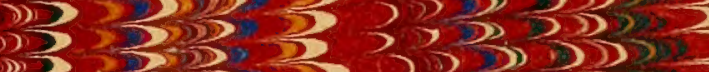
M 3202503

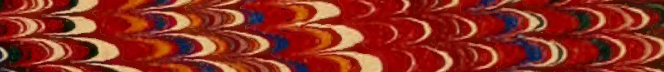
$M 325,23253$ ) 352532320

33030
()) 32300
3535353 
